\title{
PEMBERDAYAAN MASYARAKAT BERBASIS MASJID DALAM PERSPEKTIF DAKWAH NABI SAW.
}

\author{
Cucu Nurjamilah \\ Institut Agama Islam Negeri Pontianak \\ cucu_nurjamilah@yahoo.com
}

\begin{abstract}
Da'wah of social empowerment is the real action in order to make the improvements. Historically, da'wah in the form of social empowerment based on mosque has been portrayed by the Prophet in the Nabawi Mosque Madinah. Mubammad saw. has successfully repaired and changed the conditions of the Medina people into a new powerfull society. Forms of empowerment included empowering spiritual aspect, social (of unity and equality), education, economics, politics and defense. The steps in empowerment, was to grow and to build the spiritual potential of Tawheed communities, providing access to (social institutions) building a mosque, made peace agreement with the various parties, established markets around the mosque, formed and trained defense forces, and togetherness.
\end{abstract}

Keywords: social empowerment, mosque, the da'wah.

\begin{abstract}
Abstrak
Dakwah pemberdayaan masyarakar merupakan gerakan dakwah yang bersifat tindakan nyata, guna mewujudkan perubahan. Secara historis, dakwah dalam bentuk pemberdayaan masyarakat berbasis masjid telah diperankan oleh Rasulullah saw. di Masjid Nabawi Madinah. Nabi telah mampu memperbaiki dan mengubah kondisi masyarakat Madinah dan sekitarnya menjadi sebuah masyarakat baru yang maju dari semua sisi. Bentuk pemberdayaan yang dilakukan meliputi pemberdayaan dalam aspek spiritual, aspek sosial (persatuan dan kesetaraan), pendidikan, ekonomi, politik dan pertahanan. Adapun langkah yang ditempuh dalam melakukan pemberdayaan, adalah menumbuhkan dan membangun potensi spiritual Tauhid masyarakat, menyediakan akses (pranata sosial) dengan: membangun masjid, membuat perjanjian damai dengan berbagai pihak, mendirikan pasar di sekitar masjid, membentuk dan melatih pasukan pertahanan, dan kebersamaan.
\end{abstract}

Kata kunci: pemberdayaan, masjid dan dakwah

ISSN 2527-8401 (p) 2527-838X (e)

(C) 2016 JISH Pascasarjana UIN Walisongo Semarang

http://journal.walisongo.ac.id/index.php/jish 


\section{Pendahuluan}

Pada saat ini, pengembangan fungsi masjid sebagai pusat dakwah khususnya dakwah dengan bentuk pemberdayaan masyarakat merupakan suatu hal yang urgen. Hal ini berkaitan dengan kondisi negatif yang semakin mengemuka di masyarakat yang disebabkan kurangnya pemahaman dan pengalaman beragama, rendahnya ilmu pengetahuan serta lemahnya ekonomi pada sebagian masyarakat.

Dakwah pemberdayaan sama dengan gerakan dakwah menuju transformasi sosial, yakni dakwah yang dijabarkan dalam gerakan pembebasan dari eksploitasi, dominasi, penindasan, serta ketidak adilan dalam semua aspeknya. Dari gerakan inilah selanjutnya lahir dan membentuk masyarakat yang memiliki kecanggihan sosial (Puteh, 2006: 161).

Gerakan dakwah Pemberdayaan masyarakat berbasis masjid telah sukses dijalankan Rasulullah saw.. Beliau telah berhasil mengubah dan membangun sebuah masyarakat muslim melalui gerakan dakwah dari masjid Nabawi di Madinah. Pada masa keemasan Islam, di samping sebagai pusat ibadah, masjid telah mampu menjadi pusat kebudayaan masyarakat Islam. (Gazalba, 1989: 141).

Tulisan ini akan menyajikan hasil penelitian pustaka mengenai pemberdayaan masyarakat berbasis masjid dalan perspektif dakwah Nabi saw.

\section{Pemberdayaan Masyarakat, Pengertian dan Tujuan}

Menurut Suharto (2009: 57), kata pemberdayaan atau pemberkuasaan (empowerment) berasal dari kata "power" (kekuasaan atau keberdayaan). Menurutnya, ide utama pemberdayaan bersentuhan dengan konsep kekuasaan. Kekuasaan yang dimaksud adalah kekuasaan yang dapat dirubah dan dinamis, yakni kekuasaan yang senantiasa hadir dalam konteks relasi sosial antar manusia. Suharto berpandangan bahwa pemberdayaan merupakan sebuah proses dan tujuan. Sebagai proses, pemberdayaan adalah serangkaian kegiatan untuk memperkuat kekuasaan atau keberdayaan kelornpok lemah dalam masyarakat, termasuk individu-individu yang 
mengalami masalah kemiskinan. Sebagai tujuan, pemberdayaan menunjuk pada keadaan atau hasil yang ingin dicapai oleh sebuah perubahan sosial; yaitu masyarakat yang berdaya, memiliki kekuasaan atau mempunyai pengetahuan dan kemampuan dalam memenuhi kebutuhan hidupnya baik yang bersifat fisik, ekonomi, maupun sosial seperti memiliki kepercayaan diri, mampu menyampaikan aspirasi, mempunyai mata pencaharian, berpartisipasi dalam kegiatan sosial, dan mandiri dalam melaksanakan tugas-tugas kehidupannya.

Pendapat yang sama dikemukakan oleh Kartasasmita (2003) yang memberikan pengertian dari kata "berdaya". Menurutnya, keberdayaan dalam konteks masyarakat adalah kemampuan individu yang bersenyawa dalam masyarakat dan membangun keberdayaan masyarakat yang bersangkutan. Keberdayaan masyarakat adalah unsur-unsur yang memungkinkan suatu masyarakat bertahan (survive), dan dalam pengertian yang dinamis mengembangkan diri dan mencapai kemajuan. Unsur-unsur yang dimaksud adalah berupa nilai-nilai yang dimiliki individu sebagai anggota masyarakat. Nilainilai tersebut terdiri dari unsur fisik (seperti sehat, terdidik, kuat dan inovatif) dan nilai intrinsik seperti nilai kekeluargaan, kegotongroyongan, kejuangan dan kebhinekaan.

Beberapa pendapat di atas menunjukkan bahwa upaya pemberdayaan diawali pada individu yang didukung dengan pemberdayaan pada pranata sosialnya sehingga menghasilkan masyarakat yang berkompetens.

Menurut Kartasasmita (2003), beberapa tahapan yang umumnya dilakukan dalam upaya pemberdayaan masyarakat adalah sebagai berikut: pertama, menciptakan suasana atau iklim yang memungkinkan potensi masyarakat berkembang (enabling). Pada tahap ini titik tolaknya adalah pengenalan bahwa setiap manusia, setiap masyarakat, memiliki potensi yang dapat dikembangkan. Kedua, memperkuat potensi atau daya yang dimiliki masyarakat (empowering). Pada tahap ini diperlukan langkah-langkah lebih positif, selain dari hanya menciptakan iklim dan suasana. Langkah positif dimaksud meliputi langkah-langkah nyata, dan menyangkut penyediaan berbagai masukan (input), serta pembukaan akses ke dalam berbagai 
peluang (opportunities) yang akan membuat masyarakat menjadi berdaya. Ketiga, memberdayakan mengandung pula arti melindungi. Dalam proses pemberdayaan, harus dicegah yang lemah menjadi bertambah lemah oleh karena kekurang berdayaan dalam menghadapi yang kuat. Oleh karena itu, perlindungan dan pemihakan kepada yang lemah amat mendasar sifatnya dalam konsep pemberdayaan masyarakat.

\section{Dakwah Pemberdayaan Masyarakat Berbasis Masjid}

\section{Hakikat Dakwah}

Ditinjau dari aspek bahasa, kata dakwah merupakan bentuk masdar dari da'a, yad'u, da'watan. Dalam kamus bahasa Arab kata "dakwah" yang terbentuk dari tiga huruf, yaitu dal, 'ain, dan wawn memiliki beberapa arti, yaitu memanggil, mengundang, minta tolong, meminta, memohon, menamakan, menyuruh datang, mendorong, menyebabkan, mendatangkan, mendo'akan, menangisi dan meratapi (Munawwir, 1997: 407). Dengan memperhatikan bentukan kosa katanya yang berupa kata benda (ism) dan terambil dari fi'il muta'addi, menurut Muhyiddin (2002: 27), makna-makna di atas seperti seruan, ajakan dan sebagainya, mengandung nilai dinamika. Artinya makna tersebut memiliki unsur usaha atau upaya yang dinamis. Unsur dinamika dalam dakwah mengandung arti bahwa dakwah hadir sebagai upaya solusi persoalan-persoalan yang sedang dan akan dihadapi ummat. Dalam kata lain bahwa dakwah adalah upaya perubahan masyarakat. Berbicara perubahan masyarakat, inilah pemberdayaan masyarakat. Dari lemah menjadi kuat, dari ketergantungan menjadi mandiri dan percaya diri.

Berkaitan dengan makna dakwah sebagai upaya pemberdayaan, Achmad (1985: 7), menyatakan, bahwa kegiatan dapat disebut dakwah jika merupakan sistem usaha bersama orang beriman dalam rangka mewujudkan ajaran Islam dalam semua segi kehidupan sosiokultural yang dilakukan melalui lembaga-lembaga dakwah. Ditegaskan Mubarak (2005: 27), aktivitas dakwah pada hakikatnya merupakan suatu proses mengadakan perubahan secara normatif sesuai dengan al-Qur'an dan hadits Nabi saw. Berkaitan dakwah 
dalam konteks sosio cultural, dalam pandangan Muhyiddin (2002: 3536), dakwah merupakan upaya memperkenalkan Islam sebagai satusatunya jalan hidup yang benar, dengan cara yang menarik, bebas, demokratis, dan realistik menyentuh kebutuhan primer manusia dengan tegak berdiri di atas landasan ajaran-ajaran yang prinsip.

Beberapa pengertian di atas, menunjukkan bahwa tujuan dakwah adalah perubahan manusia secara individu dan kelompok, dengan mewujudkan ajaran Islam pada seluruh aspek kehidupan manusia. Dalam upaya realisasi tujuan dakwah tersebut, menurut Munir dan Ilaihi (2009: 66), dakwah dilakukan secara professional yang ditata dan dikelola secara baik dalam sebuah organisasi dakwah dengan menerapkan prinsip-prinsip manajerial yang baik pula. Dijelaskan oleh Muhyiddin (2002: 133-136), bahwa upaya dakwah secara professional dilakukan melalui tahapan-tahapan berikut: (1) perencanan kegiatan dakwah, meliputi penetapan tujuan dakwah, merumuskan kondisi sasaran dakwah, mengidentifikasi kemudahan dan hambatan, dan mengembangkan rencana dakwah; (2) pengorganisasian dakwah, meliputi: merancang aktivitas dakwah yang efektif, mengelompokan kegiatan-kegiatan berdasarkan pertimbangan tertentu, membagi tugas dakwah; (3) pelaksanaan dakwah sesuai skala prioritas, sasaran, kebutuhan, target dan tujuan; (4) evaluasi dakwah yang dilakukan di awal, bersamaan dengan pelaksanaan, umpan balik.

2. Dakwah Pemberdayaan Masyarakat

Menurut Yusuf (t.t: 11), untuk istilah dakwah pemberdayaan, dalam bahasa Arab berasal dari kata "at-Tamkin", yaitu merupakan bentuk masdar dari kata "makkana-yumakkinu". Ia mencontohkan "makkana fulan" memiliki arti derajatnya meningkat, dan makkana 'ala syaiin, yang artinya berkompetensi dalam bidang tertentu atau lebih unggul. Jadi menurutnya, pemberdayaan berarti menempatkan sesuatu sesuai dengan proporsinya. Kemudian Yusuf menegaskannya dengan pengertian dari kata "al-Miknab" yang merupakan masdar dari kata "makkana". Al-Miknah memiliki arti kekuatan atau kekuasaan. Pengertian ini dirujuknya dari ayat alQur'an surah al-Anfal ayat 71, yang artinya: "Maka sesungguhnya 
mereka telah berkhianat kepada Allah sebelum ini, lalu Allah menjadikan (kamu) berkuasa terhadap mereka".

Secara istilah, menurut Puteh (2006: 161), dakwah pemberdayaan sama dengan gerakan dakwah menuju transformasi sosial, yakni dakwah yang dijabarkan dalam gerakan pembebasan dari eksploitasi, dominasi, penindasan, serta ketidakadilan dalam semua aspeknya. Dari gerakan inilah selanjutnya lahir dan membentuk masyarakat yang memiliki kecanggihan sosial. Secara lebih rinci Ismail dan Hotman (2011: 225-227) menguraikan bahwa, dakwah pemberdayaan masyarakat lebih mengutamakan aksi ketimbang wacana atau rethorika (tabligh). Gerakan dakwah pemberdayaan biasanya mengejawantah dalam lembaga-lembaga swadaya masyarakat muslim yang independen dari gerakan politik massif. Dakwah pemberdayaan biasanya bergerak dalam bidang-bidang sosial, ekonomi dan pendidikan.

Dari beberapa pengertian di atas, dapat dikatakan bahwa dakwah pemberdayaan masyarakat adalah: a) Gerakan dakwah yang bersifat tindakan nyata untuk mewujudkan perubahan yakni peningkatan kualitas keagamaan dan kualitas sosialnya, b) Gerakan dakwah yang dilakukan secara professional dalam sebuah lembaga dakwah dengan menerapkan fungsi-fungsi manajemen modern, c) Gerakan dakwah dapat berupa pendampingan dengan melibatkan berbagai pihak, d) Däi dalam gerakan dakwah pemberdayaan dapat bertindak sebagai motivator dan fasilitator, e) Yang menjadi sasaran dakwah pemberdayaan, adalah masyarakat yang memiliki kondisi lemah, dan f) Materi dakwah pemberdayaan masyarakat, tidak hanya materi keislaman, tetapi meliputi berbagai aspek yang menyangkut peningkatan kualitas hidup manusia

3. Pilar-Pilar Pemberdayaan untuk Sasaran Masyarakatnya

Untuk mengembalikan kekuasaan, atau mewujudkan masyarakat yang berdaya (mandiri, mampu, kuat, kuasa), terdapat syarat dasar yang menjadi sandaran utama khususnya bagi tegaknya masyarakat Islam. Yang dimaksud syarat utama dalam pemberdayaan masyarakat Islam, diistilahkan oleh Yusuf (t.t: 28-30) dengan pilar-pilar pemberdayaan (muqannamatut tamkin). Menurutnya terdapat tujuh 
pilar pemberdayaan masyarakat Islam yang dijadikan landasan pokok dalam dakwah pemberdayaan, yaitu: 1) keimanan, 2) amal shalih, 3) ibadah, 4) ilmu pengetahuan, 5) jihad fi sabilillah, 6) Memohon pertolongan kepada Allah, dan 7) sabar

4. Masjid sebagai Media Dakwah

Penamaan masjid berasal dari bahasa aslinya (Arab), yaitu dari sajada-sujud yang berarti patuh taat serta tunduk dengan penuh hormat dan takzim (Shihab, 2001: 459). Kemudian menjadi bentukan kata masjid merupakan isim makan yang berarti tempat sujud. Dengan demikian, penamaan ini menunjukan fungsi utama masjid adalah tempat sujud (menjalankan ibadah shalat). Dalam pengertian seharihari yang diketahui masyarakat, umumnya masjid merupakan tempat shalat kaum muslimin. Namun demikian, menurut Shihab karena akar katanya mengandung makna tunduk dan patuh, maka hakikat masjid adalah tempat melakukan segala aktivitas yang menunjukan kepatuhan kepada Allah swt. semata sebagaimana termuat dalam alQur'an surah al-Jin ayat 18.

Ditinjau dari system dakwah, masjid merupakan sarana atau media yang menghantarkan manusia kepada jalan Allah swt. Dengan demikian, masjid adalah termasuk diantara media dakwah. Jika kegiatan-kegiatan dakwah masjid dikelola dengan sungguh-sungguh secara profesional, maka fungsi dakwah akan mampu menyentuh dan memberdayakan masyarakat sekitar masjid.

\section{Pemberdayaan Masyarakat Berbasis Masjid dalam Perspektif Dakwah Nabi saw.}

Tujuan Nabi saw. melakukan pemberdayaan masyarakat adalah untuk:

1. Membebaskan Manusia Melalui Tauhid

Ketika pertama kali Nabi saw. diutus Allah swt. berdakwah di Kota Makkah, kondisi Makkah dan hampir seluruh wilayah Jazirah Arab adalah penyembah berhala (Mubarakfuri, 2014: 10-21). Keyakinan yang menyimpang dari ajaran Nabi Ibrahim As ini, melahirkan sikap dan perilaku sosial yang menyimpang juga. Di antaranya menganggap tidak penting dengan kegiatan baca tulis. 
fanatisme kesukuan, wanita tidak dihargai dan dianggap sebagai beban hidup, buruknya perekonomian yang mengakibatkan kemiskinan, perbudakan, eksploitasi kaum lemah untuk dipaksa kerja tanpa upah terjadi di mana-mana. (Engineer, 2006: 42-46).

Kondisi yang sama juga terjadi di kota Yatsrib (Madinah) yang menjadi tempat kedua Nabi berdakwah, memiliki berbagai suku, diantaranya suku Arab terbesar adalah Aus dan Khazraj, serta bangsa Yahudi adalah Bani Nadhir, Quraizah dan Qainuqa'. fanatisme suku, perebutan kekuasaan lahan, menjadikan kehidupan di Yatsrib diliputi konflik suku yang berkepanjangan (Umari, 1999: 63-67)

Diawali dari kota Makkah Rasulullah saw. melakukan pemberdayaan terhadap unsur terpenting pada manusia, yaitu aspek mental tauhid. Nabi saw. menyampaikannya dengan mendialogkan Al-Qur'an



"Dan sunggub jike kamu bertanya kepada mereka: "Siapakah yang menciptakan langit dan bumi?", niscaya mereka menjawab: "Allab". Katakanlab: "Maka Terangkanlah kepadaku tentang apa yang kamu seru selain Allah, jika Allah hendak mendatangkan kemudharatan kepadaku, Apakah berhala-berhalamu itu dapat mengbilangkan kemudharatan itu, atau jika Allah hendak memberi rabmat kepadaKu, Apakah mereka dapat menahan rabmatNya?. Katakanlab: "Cukuplah Allah bagiku". kepada- Nyalah bertawakkal orang-orang yang berserah diri. (Al-Zumar: 38)

Demikian juga dalam menghadapi orang-orang Quraisy yang terkungkung dengan tradisi masyarakat yang menyimpang, maka Nabi menghadapinya dengan jawaban al-Qur'an yang memiliki daya tarik yang luar biasa, seperti terhadap Abu Jahal, Abu Lahab dan yang lainnya (Hisyam, jilid I) 
Dalam membebaskan masyarakat Quraisy, Rasulullah saw. melakukannya dengan tahapan yang matang.

Pertama, selama tiga tahun perubahan dilakukan secara sembunyi-sembunyi. Langkah ini dilakukan, guna membentuk pasukan yang siap bekerja bersamanya untuk membentuk mental tauhidullah. Komunitas muslim pertama dengan jumlah yang kecil yang terdiri dari tokoh-tokoh Quraisy, diantara adalah Utsman bin Affan, Az-Zubair bin Al-Awwam, Abdul Rahman bin Auf, Sa'd bin Abi Waqash, dan Thalhah bin Ubaidillah At- Taimi, Ja'far bin Abi Thalib, Abu 'Ubaidah, 'Amir Ibn Jarrah, Abu Salamah, Abu dzar alGhifari, dan lain-lain (Hisyam: 118)

Kedua, dalam dakwah terbukanya selama di Makkah, Rasulullah saw. tidak melakukan perlawanan terhadap penolakan yang diberikan Quraisy. Rasulullah menghindari peperangan yang membawa kehancuran.

Ketiga, ketika pemberdayaan di Makkah belum maksimal karena kuatnya penolakan dan serangan dari kaum Quraisy, Rasulullah dan kaum muslimin pergi berhijrah ke tempat yang sudah ada tanda-tanda kemenangan, yaitu Yatsrib (Madinah). Pemberdayaan mental tauhidullah dilanjutkan di Madinah dan dikuatkan di dalam masjid.

2. Membangun Masyarakat Muslim yang mandiri.

Di Makkah, sangat dikenal diutusnya Nabi Ibrahim dan penerusnya Nabi Ismail dengan syari'at Islam dan tauhidullah ajarannya. Namun sepeninggal keduanya lambat laun ajaran itu bergeser dan terjadi penyimpangan, hingga terjadi kehancuran moral yang luar biasa pada masyarakat Arab (Shihab, 2014: 82-83). Pemberdayaan mental bertauhid yang dilakukan Rasulullah di Jazirah Arab tidak berhenti pada pengakuan dari seorang muslim yang hanya diyakini dalam hati semata. Beliau menyampaikan ketauhidan itu diterapkan secara nyata dalam berbagai aspek kehidupan (politik, ekonomi, social dan budaya), sehingga terjadi perubahan yang besar, dari masyarakat yang menyimpang menjadi masyarakat muslim yang kuat.

Di Madinah dalam upaya mewujudkan masyarakat muslim yang bertauhid, selama sepuluh tahun, Rasulullah saw. melakukan langkah 
nyata, yaitu: a) menanamkan keimanan kepada Allah Yang Maha Esa, maka dibangunlah masjid b) Penanaman pentingnya ibadah dan amal shalih dan harus menjadi milik setiap muslim c) penanaman pentingnya ilmu pengetahuan bagi manusia, maka Rasulullah menyiapkan majelis ilmu yang setiap saat berlangsung kajian Islam, d) menyerukan pentingnya jibad fi sabilillah dalam mempertahankan ketauhidan, kebaikan dan kebenaran, e) menanamkan pentingnya doa memohon pertolongan kepada Allah dan disertai sikap sabar dalam menjalankan segala aktivitas.

Adapun bentuk pemberdayaan masjid Rasulullah saw.. meliputi beberapa aspek diantaranya

\section{Pemberdayaan Aspek Spriritual}

Pemberdayaan aspek spiritual sudah diawali ketika di Makkah dan Rasulullah berhasil membentuk komunitas kecil kaum muslimin yang selanjutnya menjadi pionir-pionir pejuang dakwah di Madinah bersama Nabi saw.. Ketika terjadi tekanan dari kaum Quraisy dan posisi kaum muslimin sangat sulit untuk menjalankan ibadahnya, Rasulullah saw. memilih hijrah ke Madinah. Kegiatan hijrah Nabi ke Madinah diawali oleh para sahabat. Ada yang hijrah sebelum Ba'iat kubra, namun sebahagian besar setelah Ba'iat 'Aqabah kedua (Hisyam, II/ 468). Sementara Rasulullah baru menyusul setelah sekitar dua bulan setelah Bai'at. Rasulullah saw. meninggalkan rumahnya pada malam hari tanggal 27 Shafar tahun 14 kenabian. Dengan ditemani Abu Bakar, beliau berhasil mengecoh kaum Quraisy yang telah seharian mengepung rumahnya. Dengan menempuh jalan yang tidak biasanya, Rasulullah berhasil lolos meninggalkan kejaran musuh dan singgah di Gua Gunung Tsaur. Setelah tiga malam berada di Gua Tsaur, dengan dipandu seorang penunjuk jalan yaitu Abdullah bin Uraiqith, Rasulullah saw. melanjutkan perjalanan menuju Yatsrib (Katsir, 2014: 115-117).

Setelah sekitar tujuh bulan Nabi saw. menetap di rumah seorang Bani an-Najar yang bernama Abu Ayub (Chalil, 2001: 465), di lokasi itu pula tepatnya di depan rumah Abu Ayub Rasulullah membeli sebidang tanah milik dua orang yatim (Sahl dan Suhail) yang selanjutnya digunakan pembangunan masjid yang dikenal dengan 
Masjid Nabawi (Ath-Thabari, 2011: 111-112). Selanjutnya setelah selesai dibangun masjid dan di sisi masjid dibangun tempat tinggal Nabi dengan sangat sederhana (Katsir, 2014: 120). Nabi saw. turun langsung dalam pembangunan masjid, memindahkan bata dan bebatuan yang diikuti oleh para sahabat dari kalangan Muhajirin dan Anshar (Al-Mubarakfuri, 2014:210)

Setelah Nabi saw. membangun Masjid Nabawi dan dikumandangkanya seruan adzan oleh Bilal bin Rabbah di setiap waktu shalat, kaum muslimin menemukan ketenangan dan kebebasan dalam menjalankan ibadah yang selama sepuluh tahun tidak didapatkannya di Makkah.

\section{Pemberdayaan Aspek Sosial}

Masjid Nabawi yang dibangun sebagai pusat ibadah dan aktivitas kaum muslimin, telah mampu menghapus seluruh sikap sosial yang lemah pada masyarakat Arab (fanatisme suku, konflik berkepanjangan, dsb). Rasulullah memerintahkan, mengajari dan membimbing dalam mensucikan jiwa kaum Muslimin. Beberapa upaya yang dilakukan Nabi dalam membangun sikap sosial masyarakat Islam, antara lain: a) Dengan pengalaman ruhani di dalam masjid, seperti shalat berjama'ah, b) Melalui pendidikan di masjid Nabawi dan tauladan Rasulullah yang secara terus-menerus ditanamkannya. Seperti penyampaian ayat-ayat al-Qur'an dan hadis tentang persamaan dan kesetaraan manusia dalam Islam, (Qs. AlHujurat: 13) pentingnya persaudaraan, serta keharusan bekerja sama antara laki-laki dan perempuan dalam menyerukan dan menegakkan kebaikan. (Qs. At-Taubah:71) Pendidikan akhlak yang diberikan Rasulullah bersifat integral, tidak hanya nashihat lisan, tetapi tauladan dari sifat dan perilaku beliau sangat mulia sesuai dengan al-Qur'an (Zuraidah dan Aizan, 2015), c) Nabi melakukan penguatan persaudaran diantara dua kelompok muslim dengan "bentuk mempersaudarakan" antara kelompok Muhajirin dan Anshar. Fenomena ini memberikan pengaruh spiritual yang amat besar yang dapat dirasakan dalam kelompok masyarakat Madinah pada waktu itu, d) Dalam setiap kesempatan Nabi memberikan perlakuan dan kesempatan yang sama kepada seluruh Muslim baik Anshar maupun 
Muhajirin. Seperti memberi kesempatan mengumandangkan adzan pada Bilal yang sebelumnya ia seorang budak hitam. Dalam setiap kumpulan musyawarah, Rasulullah meminta suara yang sama kepada kalangan Anshar dan Muhajirin. Demikian juga dalam komando jihad, pemegang bendera Islam serta pejuang yang diminta maju untuk berduel menghadapi musuh Quraisy.

3. Pemberdayaan Aspek Pendidikan

Nabi melakukan pemberdayaan pada aspek pendidikan. Dimulai di Makkah, Rasulullah saw. menyeru kepada kaum Quraisy, mengajarkan dan membimbing kaum muslimin dengan kandungan al-Qur'an secara dialogis. Nabi saw. menginginkan Islam diterima dengan keyakinan dan kesadaran yang tinggi berlandaskan ilmu pengetahuan dan keimanan. Ketika di Makkah komunitas muslim periode awal, secara intensif menerima bimbingan dan riyadlah bersama Nabi saw. di rumah Arqam bin Abi Arqam (Shihab, 2014: 338)

Selama di Madinah, pendidikan kaum muslimin di pusatkan di Masjid Nabawi. Laki-laki dan perempuan diberi kesempatan yang sama untuk mengikuti pendidikan. Materi pendidikan berupa penyampaikan nilai-nilai dari al-Qur'an yang disampaikan dalam bentuk penyampaian umum dan halaqah atau duduk melingkar mengerumuni Nabi di sela-sela shalat wajib. Ada juga di setiap pertemuan dan perjalanan bersama Nabi. Bagi muslimah ada yang langsung bertanya tentang satu permasalahan kepada Nabi, ada juga yang disampaikan kepada para istri nabi dan disampaikannya kepada baginda.

Abu Hurairah di antara shahabat Nabi yang banyak kebersamaan bersama beliau menyatakan, ketika Rasulullah sedang menyampaikan di suatu majelis pada suatu kaum, datanglah seorang kampung dan berkata,'kapankah kiamat itu?' Rasulullah terus berbicara, lalu sebahagian kaum berbicara. Kemudian Anas bin Malik shahabat Nabi juga menjelaskan, ketika ia bersama shahabat lainnya duduk bersama Nabi di masjid, masuklah seorang laki-laki yang menanyakan dan mencari Nabi saw. Istri Nabi Ummu Salamah r.a menjelaskan bahwa suatu waktu Ummu Sulaim (istri Abu Thalhah) datang kepada 
Nabi dan bertanya tentang kewajiban mandi setelah bersetubuh (Shahih al-Bukhari, Bab ilmu).

Bentuk dan kegiatan pendidikan yang dilakukan Nabi saw. memang masih sederhana jika dibandingkan dengan masa sesudahnya. Namun dasar-dasar yang sudah dilakukan beliau memiliki implikasi yang sangat besar dalam kehidupan manusia di muka bumi ini.

4. Pemberdayaan Aspek Ekonomi

Masyarakat Arab dikenal sebagai pedagang atau saudagar yang sukses di Jazirah Arab. Sebagian dari mereka juga memiliki moral yang baik, seperti suka membantu dengan hartanya. Namun, yang dinilai lemah dari perilaku ekonomi mereka adanya tindakan "riba" (adanya tambahan keuntungan dalam pembayaran hutang). Perilaku riba melahirkan kelompok orang kaya yang sangat mencintai kemewahan di satu pihak dan kelompok lemah yang terlilit di pihak lain. Di Madinah orang Yahudi yang menguasai pasar ditemukan Rasulullah saw. biasa melakukan kecurangan-kecurangan.

Kondisi inilah yang menggerakkan Rasulullah saw. untuk memperbaiki perilaku ekonomi masyarakat. Penguatan ekonomi berbasis masjid dalam dakwah Nabi saw. di Madinah lebih difokuskan pada tiga hal, yaitu: pertama, penguatan etika bisnis Islami yang harus diterapkan dalam transaksi jual beli di pasar atau di tempat lainya oleh seorang muslim seperti larangan menipu, curang, haramnya perbuatan riba, dan sebagainya Kedua, dengan membangun ikatan persaudaraan di kalangan Muhajirin dan Anshar. Bantuan dari pihak Anshar kepada kaum Muhajirin yang sedang lemah dalam ekonomi, secara perlahan Muhajirin merintis perekonomiannya. Dengan bantuan modal, ada yang memulai usaha/berdagang di pasar, seperti yang dilakukan Abdurrahman bin Auf. Dengan diberikan lahan, ada yang memulai bertani, dan lain sebagainya. Sehingga lama-kelamaan kaum Muhajirin menjadi mandiri dan tidak hidup dengan ketergantungan, sekalipun mungkin sebahagian kecil ada. Bagi kaum Anshar, dengan dilandasi ketaatan kepada Allah dan Nabi-Nya, memberikan sebahagian harta kepada saudaranya yang membutuhkan akan melahirkan ketenangan jiwa dan semangat dalam 
bekerja yang tentu akan bertambah dalam keuntungan hartanya. Ketiga, dengan mendirikan pasar di sekitar Masjid Nabawi. ${ }^{1}$ Pendirian pasar bagi kaum muslimin, merupakan langkah pemberdayaan ekonomi umat Islam, yakni penyediaan lembaga ekonomi umat Islam sekaligus langkah awal penerapan system ekonomi Islam. Di pasar ini Nabi melarang adanya tindakan penipuan dalam jual beli, dan juga larangan memungut pajak seperti yang biasa dilakukan orangYahudi.

5. Pemberdayaan Aspek Politik dan Pertahanan

Dalam kemampuan bela Negara, Nabi telah berusaha memberikan penguatan-penguatan sekaligus pengalaman, diantaranya:

a. Pengalaman berhijrah. Bentuk perlawanan Nabi terhadap tekanan kaum Quraisy dalam mempertahankan keimanan diri dan ideologi, komunitas eksistensinya, dan pengembangan masyarakat Islam, dalam kondisi lemah pilihanya adalah hijrah. Tindakan hijrah bukan sebuah pelarian menghindari kekalahan, melainkan bentuk perlawanan, dalam memertahankan kedaulatan Negara

b. Pembangunan masjid. Untuk membangun sebuah kekuatan, dibutuhkan tempat atau markas dimana kaum muslimin dapat bertemu secara intensif. Masjid bukan hanya tempat beribadah, kaum muslimin bertemu untuk bermusyawarah, serta setiap saat Nabi memberikan penguatan-penguatan berupa motivasi, harapan dan janji-janji Allah bagi mereka yang menolong agama Allah. Dari Masjid Nabawilah kekuatan Islam bergema hingga mampu menaklukan Kota Makkah²

1 Diriwayatkan oleh Ibnu Majah, "Inilah pasar kalian, jangan sampai dikurangi dan jangan juga menetapkan pajak atasnya"

2 Seperti dikemukakan shahabat Anas bin Malik, Nabi Saw. pernah menyampaikan nashihatnya," Sungguh pergi pada waktu sore atau waktu pagi hari di jalan Allah lebih baik daripada dunia dan seisinya. Dan sungguh jarak ujung busur panah salah seorang dari kamu di surga atau tempat cambuknya adalah lebih bagus daripada dunia dan seisinya. Dan sungguh seandainya seorang perempuan (bidadari) dari penghuni surge muncul ke penduduk bumi, niscaya ia menerangi cakrawala antara keduanya (langit dan bumi) dan bau wanginya memenuhi cakrawala itu, dan sungguh kerudung di atas kepalanya adalah lebih bagus daripada dunia dan isinya" (Shahih Bukhari, Juz 4, Bab Jihad: 800) 
c. Menggalang persatuan umat Islam. Dimulai dari mempersaudarakan Muhajirin dan Anshar

d. Menjalin kerukunan antar umat beragama yang berada di Madinah yang menghasilkan kesepakatan damai, yang dikenal dengan "perjanjian piagam Madinah"

e. Mengadakan perjanjian damai dengan beberapa kabilah yang berada di sekitar jalur perlintasan dagang dari Makkah menuju Syam $^{3}$

f. Latihan persiapan perang, seperti memanah, serta nashihatnashihat tentang pentingnya memiliki keterampilan dalam membela Negara serta pentingnya membangun kekuatan komunitas

g. Latihan keberanian dengan pengiriman pasukan secara terusmenerus untuk membangun kekuatan kaum muslimin ke hadapan musuh Islam $^{4}$

h. Kebersamaan dengan Nabi di medan peperangan. Kaum muslimin menyaksikan, merasakan dan mempraktekan tahapantahapan menjelang pertempuran, serta strategi peperangan yang dikomando oleh Nabi secara langsung. Mereka juga menyaksikan kesungguhan Nabi dalm membela agama Allah,

${ }^{3}$ Pada tahun pertama hijrah Rasulullah memimpin langsung 70 rombongan Muhajirin di Abwa' atau waddan. dalam ghzwah ini Nabi melakukan perjanjian dengan Bani Dhamrah/ 'Amar bin Makhsya adh-Dhamri (yang dikenal memiliki pasukan kuat) yang isinya menjamin keselamatan diri dan harta mereka dan bahwa mereka akan dibantu menghadapi siapa pun yang bernaksud buruk (AthThabari, tt: 12-14)

${ }^{4}$ Pada tahun pertama hijrah, diantaranya Rasulullah mengutus Ubaidah bin al-Harits bin al-Muthalib memimpin 60 Muhajirin dan bertemu dengan rombongan Abu Sufyan. Pada pertemuan ini Sa'ad bin Abi Waqas tercatat sebagai orang pertama yang berhasil meluncurkan anak panah kepada musuh Islam (Hisyam, II/591). Kemudian utusan yang dipimpin Abdullah bin Jahsyi, Rasulullah memberikan surat rahasia yang harus dibuka ketika sudah melakukan perjalanan dua hari. Abdullah bin jahsyi memegang dan menjalankan amanah Rasulullah tersebut, yang akhirnya rombongan ini bertemu dengan rombongan Quraisy di Nakhlah dan di sinilah pertama kali kaum muslimin berperang melawan Quraisy dan terdapat seorang Quraisy terkena panah hingga mati serta membawa tawanan (Ath-Thabari, II/ 121). Pasukan ini sebenarnya merupakan pasukan mata-mata kepada kaum Quraisy (Wahab, tt: 173) 
dan merupakan tauladan bahwa keterlibatan pimpinan merupakan hal yang penting ${ }^{5}$

\section{Langkah-langkah Nabi saw. dalam Pemberdayaan Masyarakat Berbasis Masjid}

1. Menumbuhkan dan Membangun Potensi ke-Islaman
Dibalik kelemahan-kelemahan yang sedang dialami masyarakat, Nabi saw. melihat adanya potensi ke-Islaman pada diri mereka. Dalam upaya menumbuhkan potensi tersebut, maka Nabi saw. berusaha menawarkan Islam kepada berbagai kalangan bangsa Arab dengan bijak dan tegas melalui penyampaian wahyu secara dialogis. ${ }^{6}$ Ketika kelompok muslim mendapat tekanan, Nabi saw. berusaha

${ }^{5}$ Bermusyawarah dalam setiap menjelang pertempuran. Menjelang perang Uhud seperti disebutkan dalam surah ali-Imran ayat 121. Dijelaskan Shihab (2014: 612), menjelang terjadinya perang Uhud, pada hari jum'at pagi 14 Syawal 3 hijrah Rasulullah meninggalkan keluarganya menuju Masjid untuk membeicarakan tentang menghadapi serangan Quraisy di bukit Uhud. Menjelang kecamuk perang Badar, terjadi yang disebut dengan "majelis musyawarah militer". Dalam majelis ini Rasulullah menawarkan pendapatnya dan mempersilahkan para komandan perang untuk menyampaikan pendapatnya dalam kedediaanya berperang (Al-Mubarakfuri, 2014: 238).

Nabi saw. menerima usul dari sahabat. Dalam musyawarah perang Badar, Rasulullah menerima usul dari sahabat Hubab bin Mundzir yang mengusulkan untuk menempati mata air yang lokasinya paling dekat dengan perkemahan Quraisy. Kemudian juga ada usul dari Sa’ad bin Muadz yang mengusulkan untuk membangun kemah (arsy) khusus untuk Nabi, menyiapkan hewan kendaraan serta usul agar menyerang musuh (Ath-Thabari, 1988: 29-30). Dalam musyawarah Khondaq, sahabat dari Persia Salman al-Farisi mengusulkan pembuatan parit di wilayah utara Madinah (Al-Bauthi, tt: 290)

Senantiasa berdoa. Rasulullah selalu memanjatkan doa kepada Allah di setiap peperangan. Paada pertempuran Badar rasulullah terus-menerus berdoa hingga serbannya terjatuh dari pundaknya. Doanya,"ya Allah, sempurnakanlah kepadaku segala apa yang telah Engkau janjikan kepadaku. Ya Allah jika engkau membinasakan pasukan Islam, tentulah Engkau tidak akan lagi disembah di muka bumi ini". Selesai berdoa Allah mengabulkan doanya dengan menurunkan surah al-Anfal ayat 9 (Ath-Thabari, 1988: 33)

6 Di saat memperoleh ejekan dan umpatan dari Abu lahab, maka jawabannya turunlah surah al-Lahab yang isisnya ancaman dari allah yang akan diterima Abu Lahab. Kemudian ketika salah satu pemuka Quraisy, 'Utbah bin Rabi'ah" menemui nabi dan mengajak berunding, setelah Uthbah berbicara lalu rsulullah Saw. menyampaikan ayat (Qs Fushshilat, 1-5) dan membuat uthbah tercenung (Hisyam, I/164) 
meyakinkannya dan secara terus-menerus memupuk ke-Islaman mereka dengan wahyu. ${ }^{7}$

2. Menguatkan dan memelihara ke-Islaman masyarakat dengan tersedianya pranata sosial

Potensi ke-Islaman yang sudah tumbuh, langkah selanjutkan diperkuat dengan berbagai akses yang memungkinkan terwujudnya masyarakat muslim berkualitas. Di antara langkah Nabi saw. adalah:

Pertama, Nabi membangun lembaga keagamaan yaitu masjid. Di masjid ini Nabi menjalankan berbagai upaya pemberdayaan, diantaranya: a) Memperkuat ketauhidan. Dengan adanya Masjid Nabawi potensi ketauhidan kaum muslimin dapat berkembang. Mengingat, saat sampai di Madinah, kaum Muhajirin dalam kondisi lemah dan tertekan karena harus berpisah dari keluarga dan koleganya, serta mendapat tekanan dan ancaman dari pihak Quraisy Makkah. Sementara kaum Anshar, sekalipun berada di tanah kelahiranya, namun mereka baru mengenal Islam. Untuk itu Nabi memerlukan sebuah tempat dimana beliau dapat bertemu dengan seluruh kaum muslimin dan memberikan penguatan-penguatan ketauhidan. Nabi saw. membimbing dan menjalankan pengalaman ruhani (shalat, tilawah dan memahamkan al-Qur'an) bersama-sama untuk menumbuhkan keimanan dan kesadaran mereka. b) Di masjid, dikumandangkannya adzan setiap waktu shalat, sehingga muslimin merasa memiliki kebebasan yang luas dalam menjalankan ibadah. Dengan kebebasan ini, posisi seorang muslim akan merasa lebih kuat c) Di masjid Nabi saw. mengajarkan tentang ketentuan Islam yang harus diterapkan dalam kehidupan, seperti masalah ibadah, hubungan sosial, ekonomi bahkan politik.

Kedua, Nabi membuat kesepakatan dan perjanjian damai dengan berbagai pihak. Langkah ini ditempuh untuk membebaskan kaum muslimin dari berbagai tekanan, seperti kebebasan beribadah, keterkungkungan fanatisme suku, rongrongan dari kaum Quraisy, Yahudi dan musyrikin Madinah.

${ }^{7}$ Di saat kaum muslimin mendapat tekanan/penyiksaan dari Quraisy Makkah, Nabi menasihati dan menguatkan Al-Quran Surat al-Baqarah ayat 214. 
Langkah pembebasan Nabi saw. meliputi: a) Mempersatukan kaum Muhajirin dan Anshar; b) Disepakatinya perjanjian damai dan saling memberi kebebasan antara kaum muslimin dengan kelompok yang berbeda agama di Madinah. Kedua langkah ini memberikan kesempatan kepada kaum muslimin untuk dapat bergaul secara lebih luas dan aman, serta memiliki kesempatan untuk menyeru orang lain kepada Islam. Dan ini merupakan kesempatan untuk menjadi lebih kuat.

Ketiga, didirikanya pasar di sekitar masjid. Dengan adanya pasar, kaum muslimin memiliki kesempatan dalam menerapkan nilai ketauhidannya dalam kegiatan ekonomi. Selain itu, mereka juga mengembangkan kemampuanya dalam berdagang, serta kesempatan untuk memiliki kekuatan dalam perekonomian, dan akan menambah kepercayaan bagi kaum muslimin di kalangan Yahudi Madinah

Keempat, Nabi bersama kaum muslimin membentuk pasukan pertahanan. Dengan pasukan ini, Nabi bersama kaum muslimin berlatih ketangkasan memanah, pengiriman pasukan prajurit matamata, serta membicarakan strategi peperangan dan menyelamatkan Islam dari serangan musuh. Dengan pasukan pertahanan ini kaum muslimin menjadi disegani dan ditakuti di seluruh Jazirah Arab

Kelima, Nabi senantiasa bersama kaum muslimin, memberikan tauladan, menashihatinya, memberikan perlindungan, serta menegurnya apabila mereka melakukan kekeliruan. Nabi bersikap adil dan bijak terhadap seluruh kaum muslimn serta beliau sangat menyayangi mereka. inilah bentuk perlindungan Nabi kepada kaum muslimin.

\section{Implikasi dari Pemberdayaan Masyarakat Berbasis Masjid}

Upaya pemberdayaan yang telah dilakukan Nabi saw. hasilnya dapat dirasakan di seluruh masyarakat Jazirah Arab, bahkan seluruh penjuru dunia. Dari catatan sejarah, ditemukan hasil perjuangan Nabi saw. yang merupakan sebuah peradaban baru yang tumbuh di Jazirah Arab. Temuan itu meliputi:

1. Implikasi dari Pemberdayaan Aspek Spiritual 
Selama kurun waktu di Makkah dan Madinah Nabi saw. telah berhasil mengubah keimanan masyarakat Arab, dari keterkungkungan pada banyak tuhan/berhala menjadi penyembahan pada satu tuhan (tauhid). Tidak hanya bentuk penyembahan yang dirubah, tetapi implikasi dari kekuatan ketauhidan Islam, telah mampu melahirkan pribadi bertauhid, yaitu:

a. Pribadi yang mengutamakan Allah dan Nabi-Nya. Seperti kerelaan dalam berhijrah bersama Nabi (berpisah dari keluarga dan koleganya), berbagi harta kekayaan dan kasih sayang dengan saudara muslim, berangkat ke medan tempur setiap kali Nabi mengutusnya, menjaga dan menjalankan amanah Nabi (seperti Abdullah bin Jahsy, dalam sariyah Nakhlah), ${ }^{8}$ siap menjadi syuhada dalam setiap pertempuran sehingga mereka siap bertempur sekalipun harus berhadapan satu lawan satu. Kerelaan hidup sederhana, dan tidak mengharapkan harta rampasan dari setiap peperangannya. Semua yang mereka lakukan hanya untuk Allah dan Nabi-Nya. Rakhmat (1998: 34-35) menyebutnya sebagai hamba yang memiliki taubidullah ibadah, hanya menghambakan diri kepada Allah. Ketika taubidullah ibadah telah mampu dimiliki, masyarakat yang lepas dari segala penindasan dan penjajahan, masyarakat yang adil dan makmur akan dapat ditegakkan.

b. Mampu melahirkan jiwa yang sosial di kalangan Muhajirin dan Anshar. Mereka siap menolong dan berbagi dengan saudaranya serta membela ketika saudaranya didzalimi. Seluruhnya dilakukan dalam upaya keta'atan pada Allah dan Nabi-Nya. ${ }^{9}$

8 Pada tahun pertama hijrah, diantaranya Rasulullah mengutus pasukan yang dipimpin Abdullah bin Jahsyi, Rasulullah memberikan surat rahasia yang harus dibuka ketika sudah melakukan perjalanan dua hari. Abdullah bin jahsyi memegang dan menjalankan amanah Rasulullah tersebut, yang akhirnya rombongan ini bertemu dengan rombongan Quraisy di Nakhlah dan di sinilah pertama kali kaum muslimin berperang melawan Quraisy dan terdapat seorang Quraisy terkena panah hingga mati serta membawa tawanan (Ath-Thabari, II/ 121). 
c. Pribadi yang tolerans, menghormati segala bentuk perbedaan yang ada di masyarakat Madinah, termasuk berbeda agama

d. Pribadi yang tha'at kepada hukum Allah dan mencontoh NabiNya.. Seperti, menjalankan perintah shalat termasuk dalam perubahan arah kiblat, menjalankan perintah jihad, membantu saudaranya dan bersikap baik kepada orang kafir yang tidak memusuhi agama Islam.

2. Implikasi dari Pemberdayaan Aspek Sosial (persaudaraan dan kesetaraan)

Langkah mempersaudarakan yang ditempuh Nabi saw, telah mampu mengubah dan menghapus berbagai kemacetan komunikasi sosial di kalangan bangsa Arab, yaitu:

a. Membentuk persatuan umat yang kokoh, merobohkan berbagai perbedaan yang ada (warna kulit, keturunan, dan tanah kelahiran)

b. Menumbuhkan sikap cinta ilmu pengetahuan dan pentingnya informasi yang datang dari siapapun, khususnya saudara muslim. Maka diantara kaum muslimin bukan hanya berbagi materi, tetapi selalu berbagi ilmu pengetahuan yang sudah diperolehnya dari Nabi saw. Maka lahirlah periwayat-periwayat hadis, seperti Abu Hurairah, ibnu Mas'ud dan lainya ${ }^{10}$

c. Menghapuskan budaya mengutamakan laki-laki, dan memberikan perlakuan yang sama antara laki-laki dan perempuan dalam berbagai aspek. Contohnya, dibolehkanya perempuan berpartisipasi di ruang public, seperti terlibat di masjid baik shalat maupun menuntut ilmu bersama Nabi, ${ }^{11}$

${ }^{10}$ Malik bin al-Huwairits berkata, "Rasulullah Saw. bersabda kepada kami, 'kembalilah kepada keluargamu, kemudian ajarilah mereka (Shahih Bukhari Bab Ilmu). Abu Hurairah berkata," tiada seorang pun dari sahabat Nabi Saw. yang lebih banyak dalam meriwayatkan hadits yang diterima dari belia Saw.. dari pada saya, melainkan apa yang didapat dari Abdullah bin Amr, sebab ia mencatat hadits sedang saya tidak mencatatnya (Shahih bukhari bab ilmu)

${ }^{11}$ Dalam kesempatan pengajaran dan pendidikan Islam, Rasulullah juga mengikut sertakan para perempuan yang sudah berstatus muslimah. Seperti hasil penelitian Sa'adah (2008: 55-62), bahwa (a) pada gerakan dakwah Islam secara sembunyi-sembunyi di rumah al-Arqam bi abil Arqam juga diikuti oleh muslimah, diantaranya ada Ramlah binti Abu Auf al-Sahmiyah dan Asma binti Umais; (b) pada periode Madinah, kegiatan pendidikan Islam terjadi lebih banyak dan 
bahkan terlibat dalam kancah pertempuran. ${ }^{12}$ Sehingga lahirlah muslimah periwayat hadis ${ }^{13}$

3. Implikasi dari Pemberdayaan Aspek Pendidikan

Dari catatan sejarah ditemukan adanya pengaruh yang luar biasa yang dirasakan masyarakat Arab setelah Nabi saw. melakukan pemberdayaan pada aspek pendidikan. Pengaruh itu meliputi:

a. Melahirkan para periwayat hadits baik laki-laki maupun perempuan

dilakukan secara intensif. Rasulullah Saw. memberikan waktu khusus pertemuan dengan kelompok muslimah membahas Islam. Bahkan ada pertemuan khusus membahas permasalahan perempuan di masjid Nabawi. Selain secara kolektif, beliau juga sering memberikan pendidikan secara individu, yakni memberikan kesempatan kepada para muslimah untuk menyampaikan permaslahannya seputar ibadah, rumah tangga dan kewanitaan. (c) dalam pendidikan individu lebih banyak dilakukan oleh para istri dan kerabat Nabi. Sementara perempuan lain, jika ada permasalahan mereka memohon kepada para istri Nabi untuk menyampaikan kepadanya, atau bertanya kepada mereka secara langsung. Dengan demikian, para istri Nabi mendapatkan peran tersendiri dalam proses pendidikan perempuan pada masa itu, (d) Pada sisi lain sebahagian perempuan memperoleh pendidikan tentang Islam dari orang tua mereka, suami mereka atau para perempuan yang telah mendapat pengajaran dari Nabi saw.. Hal ini dikarenakan Nabi saw. selalu memotivasi umatnya yang telah memperoleh apa yang disampaikannya untuk menyampaikan kepada keluarga mereka dan orang lain, (e) Dari hasil pendidikan dan pengajaran bersama Nabi ini, dibuktikan oleh kiprah perempuan selanjutnya adalah dalam penyampaian dan periwayatan hadis. Hampir semua istri Rasulullah saw. memiliki peran dalam periwayatan hadis. Demikian juga kerabat beliau dan ada juga dari sahabat perempuan.

12 Pada perang Uhud, terdapat beberapa muslimah, seperti Aisyah binti Abu Bakar dan Ummu Sulaim yang membawa geriba berisi air minum diberikan kepada prajurit yang sedang bertempur. dan ummu Aiman yang masuk ke medan uhud, ia memberikan minum dan sempat membidikkan anak panah yang mengenai Hibban bin Al-Ariqah orang quraisy (Al-Mubarakfuri, 2014: 324-325)

${ }^{13}$ Mengenai periwayat hadis dari kalangan perempuan, sebagaimana hasil penelitian Agung Danarto, bahwa Sababiyah yang terlibat dalam periwayatan hadis sejumlah 132 orang atau sekitar 12,6 \% dari 1046 periwayat. Istri Nabi atau ummahat al-mu'minin seperti Aisyah binti Abu Bakr, Hindun binti Abi Umayyah, Maimunah binti al-Harits, Ramlah bint Abi Sufyan, Khafshah binti Umar ibn alKhattab tercatat meriwayatkan lebih dari ratusan hadis disamping para sababiyah yang lain seperti Asma binti Abu Bakr, Zainab Binti Abi Salamah, dan Ummu Athiyah (Nur Mahmudah: 2014, http://journal.stain kudus.ac.id, diunduh pada, 21 Oktober 2015). 
b. Melahirkan para da'i yang siap diutus ke berbagai daerah di Jazirah Arab untuk menyebarkan dakwah Islam ${ }^{14}$

c. Melahirkan para pemimpin dan khalifah yang berhasil memimpin dunia

4. Implikasi dari Pemberdayaan Aspek Ekonomi

Pemberdayaan ekonomi yang dilakukan Rasulullah saw. pada waktu di Madinah, kegiatannya masih sederhana. Nabi menyampaikan nashihat-nashihat etika bisnis, seperti larangan menipu, dan berbohong dalam jual beli di pasar, larangan mengurangi timbangan, jujur, serta haramnya riba, dan sebagainya.

Konsep dan perinsip ekonomi Islam tersebut baru diterapkan di pasar yang sederhana yang dibangun Nabi bersama kaum muslimin di sekitar Masjid Nabawi. Dengan demikian, implikasinyapun pada waktu itu belum terlihat besar. Akan tetapi, dasar-dasar yang dimulai oleh Nabi dari masjid Nabawi pada periode sesudah Nabi, memiliki pengaruh yang luar biasa pada perekonomian Islam.

5. Implikasi dari Pemberdayaan Aspek Politik dan Pertahanan

Islam memiliki mujahid-mujahid tangguh yang selalu siap setiap kali Nabi menyerukan perlawanan di medan juang. Sekalipun harus berperang secara berhadapan satu lawan satu, kaum muslimin tidak pernah mundur sedikit pun. Diantaranya: paman Nabi Hamzah bin abdul Muththalib dan Hanzhalah bin Abu "Amir al-fasiq yang gugur pada perang Uhud. Ali bin Abi Thalib yang dengan berani membunuh "Amr bin Abd Wud dalam perang khandaq.

a. Seluruh wilayah Madinah, menjadi wilayah kekuasaan Islam, Makkah dapat ditaklukkan, hingga seluruh Jazirah Arab

b. Melahirkan para Khalifah yang melanjutkan kepemimpinan Rasulullah

\section{Kesimpulan}

Selama perjalanan dakwahnya Nabi saw. telah berhasil melakukan pemberdayaan masyarakat Arab berbasis Masjid Nabawi

${ }^{14}$ Di antara para da'i yang diutus Nabi Saw.: Mush'ab bin Umair yang diutus Nabi Saw. untuk mengajarkan Islam ke Madinah, Abu Umamah r.a. yang diutus Nabi kepada kaumnya Bahilah, dan lainya (Al-Kandahlawi, 2007: 121-125) 
di Madinah. Terdapat dua alasan atau tujuan penting dari pemberdayaan tersebut, yaitu: a) Membebaskan manusia dari keyakinan dan budaya menyimpang (jabiliyah), dan b) Mempertahankan dan membangun masyarakat muslim.

Bentuk pemberdayaan yang dilakukan meliputi pemberdayaan dalam aspek spiritual, aspek sosial (persatuan dan kesetaraan), pendidikan, ekonomi, politik dan pertahanan. Adapun langkah yang ditempuh dalam melakukan pemberdayaan, adalah menumbuhkan dan membangun potensi spiritual Tauhid masyarakat, menyediakan akses (pranata sosial) yaitu dengan: membangun masjid, membuat kesepakatan dan perjanjian damai dengan berbagai pihak, mendirikan pasar di sekitar masjid, membentuk dan melatih pasukan pertahanan, dan kebersamaan.

Beberapa perubahan yang merupakan implikasi dari kegiatan pemberdayaan tersebut adalah: a) Bidang spiritual melahirkan pribadi yang mengutamakan Allah dan Nabi-Nya, melahirkan jiwa yang sosial di kalangan Muhajirin dan Anshar, melahirkan Pribadi yang tolerans, dan melahirkan pribadi yang tha'at kepada hukum Allah dan mencontoh Nabi-Nya.; b) Bidang sosial mampu membentuk persatuan umat yang kokoh, menghilangkan berbagai perbedaan yang ada (warna kulit, keturunan, dan tanah kelahiran), serta menghapuskan fanatisme kesukuan dan golongan; menumbuhkan sikap cinta ilmu pengetahuan dan pentingnya informasi yang datang dari siapapun, khususnya saudara muslim; menghapuskan budaya mengutamakan laki-laki, dan memberikan perlakuan yang sama antara laki-laki dan perempuan dalam berbagai aspek; c) Pemberdayaan bidang pendidikan: melahirkan para periwayat hadits baik laki-laki maupun perempuan; melahirkan para da'i yang siap diutus ke berbagai daerah di Jazirah Arab untuk menyebarkan dakwah Islam; melahirkan para pemimpin dan khalifah yang berhasil memimpin dunia; d) Dari pemberdayaan ekonomi pada waktu itu belum terlihat besar, akan tetapi, dasar-dasar yang dimulai oleh Nabi dari masjid Nabawi pada periode sesudah Nabi, memiliki pengaruh yang luar biasa pada perekonomian Islam; d) Implikasi dari pemberdayaan aspek politik dan pertahanan adalah memiliki 
mujahid-mujahid tangguh yang selalu siap setiap kali Nabi menyerukan perlawanan di medan juang; Seluruh wilayah Madinah, menjadi wilayah kekuasaan Islam, Makkah dapat ditaklukkan, hingga seluruh Jazirah Arab; dan melahirkan para Khalifah yang melanjutkan kepemimpinan Rasulullah.

\section{Daftar Pustaka}

Achmad, Amrullah (ed), 1985, Dakwah Islam dan Perubahan sosial, Yogyakarta: PLP2M

Anwar, Saeful, 2007, Filsafat Ilmu Al-Ghazali, Bandung: Pustaka Setia Al-Baihaqi, Abu Fathan, Abu Muhammad Raisah, 2012, Al-Qur'anul Karim The Noble, Jawa Barat: Insan Media Pustaka

Al-Bauthi', Muhammad Sayid Ramadhan, tt, Figh Sirah, Beirut Libanon: Darul Kitabil Islamiyah

Baqi, Muhammad Fu;ad "Abdul, 20014, Mutiara Hadits Shabih Bukhari-Muslim, diterjemahkan oleh Arif Rahman Hakim, dari Lu'luu wal Marjan, Sukoharjo: Al-Andalus

Al-Bayanuni, Muhammad Abdul Fatah, 2001, Al-Madkball Ila TlmidDakwah, Beirut: Resalah Publishers.

Al-Bukhari, Muhammad bin Ismail, 1387H, Shabih Bukhari, Bab Jihad, Bab Ilmu India: Maktabah Rahimiyah

Aziz, Moh. Ali, 2009, Ilmu Dakwah, Jakarta: Kencana Prenada Media Group

Cholil, Moenawar, 2001, Kelengkapan Tarikh Nabi Mubammad, Jilid I, Depok: Gema Insani Press

Engineer, Asghar Ali, 2006, Islam dan Teologi Pembebasan, terj., Agung Prihantono, dari Islam And Liberation Theology Essay on Liberative in Islam, Yogyakarta: Pustaka Pelajar

Gazalba, Sidi, 1989, Mesjid Pusat Ibadah dan Kebudayaan Islam, Jakarta: Pustaka Al-Husna 
Hisyam, Ibnu, tt, Sirah Nabawiyah, Juz II, Beirut Libanon: AlMaktabah ilmiyah

Ishaq, Ibnu, tt, Sirah Nabawryah, Jilid I dan II, Beirut Libanon: Darul Kitabil Islamiyah

Ismail, A. Ilyas dan Prio Hotman, 2011, Filsafat Dakwah Rekayasa Membangun Agama dan Peradaban, Jakarta: Kencana Prenada media Grup

Al-Kandhalawi, Maulana Muhammad Yusuf, 2007, Hayatus Shababat Jilid I, terj., Ahmad Dusturi, dari Hayat al-Shahabah, Bandung: Pustaka Ramadhan

Kartasasmita, Ginanjar, 2003, Pemberdayaan Masyarakat Konsep Pembangunan yang Berakar pada Masyarakat, diunduh 10 November 2015 dari http://www.ginandjar.com/public/02PemberdayaanMasyarakat.pdf

Katsir, Al-Hafizh Abil Fida Ibnu, 2014, Sejarah Nabi Mubammad, terj. Abu Umar al-Maidani dan Umar Mujtahid, dari Al-Fushul fi Siratir Rasul saw., Solo: At- Tibyan

Khoiriyah, 2013, Memabami Metodologi Studi Islam, Yagyakarta: Teras

Moleong, Lexi, 2010, Metodologi Penelitian Kualitatif, Bandung: Rosdakarya

Al-Mubarrakfuri, Syaikh Syafiyyurrahman, 2014, Sirah Nabawizyah, terj. Kathur Suhardi, Jakarta: Pustaka Al-Kautsar

Mubarak, Muhammad Sa’id, 2005, Al-Da'wah wa al-Idarah, Madinah al- Munawarah: Dar al-Dirasah al-Iqtisadiyah

Muhyiddin, Asep, 2002, Metode Pengembangan Dakwah, Bandung: Pustaka Setia.

-------, 2002, Dakwah Dalam Perspektif al-Qur'an, Bandung: Pustaka Setia

Munawwir, Ahmad Warson, 1997, Al-Munawnir Kamus ArabIndonesia, Surabaya: Pustaka Progresif. 
Munir, M. dan Wahyu Ilahi, 2009, Manajemen Dakwah, Jakarta: Prenada MediaGroup.

Mahmudah, Nur, 2014, Pasang Surut Peran Perempuan dalam Periwayatan Hadis, Jurnal PALASTRèN Vol. 7, No. 1, Juni, diunduh pada, 21 Oktober 2015, http://journal.stain kudus.ac.id,

Rais, Amien, 1998, Taubid Sosial Formula Menggempur Kesenjangan, Bandung: Mizan

Rakhmat, Jalaluddin, 1998, Islam Alternatif Ceramah-Ceramah di Kampus, Bandung: Mizan

Saifullah, M. Jakfar Puteh, 2006, Dakwah Tekstual dan Kontekstual Peran dan Fungsinya dalam Pemberdayaan Ekonomi Umat, Yogyakarta: AK Grup

Ash-Shalabi, Ali Muhammad, Sirah Nabawiyah Sejarah Lengkap Rasulullah saw.., Jakarta: Pustaka Al-kautsar

Shihab, M. Quraish, 1996, Wawasan Al-Qur'an, Bandung: Mizan

------, 2001, Membaca Sirah Nabi Muhammad SAW. dalam Sorotan alQur'an dan Hadits Shabih, Tanggerang: Lentera Hati

Suharto, Edi, 2009, Membangun Masyarakat Memberdayakan Rakyat Kajian Strategis Pembangunan Kesejabteraan Sosial \& Pekerjaan Sosia, Bandung: PT Refika Aditama

Sujadi, 2003 "Peran Takmir Masjid Al-Maun dalam Pemberdayaan Masyarakat Lembah Sungai Gajah Wong Yogyakarta", Aplikasia, Jumal Aplikasi Ilmu Ilmu Agama, Vol. IV, No. 2 (Desember)

Syukriadi Sambas, 2009, Wilayah Kajian Ilmu Dakwah, dalam Dimensi Imu Dakwah, Bandung: Widya Padjajaran

Ath-Thabari, Ibnu Jarir, 1988, Tarikh al- Umam Wa al- Mulk Jilid 2, Beirut Libanon: Darul Kitab 
-------, 1988, Shabih Tarikh al- Thabari, terj. Beni Hamzah, dkk, Beirut Libanon: Al-Maktabah Ilmiyah

Umari, Akram Dhiyauddin, 1999, Masyarakat Madani Tinjauan Historis Kehidupan Zaman Nabi, Jakarta: Gema Insani Press

Wahab, Muhammad bin Abdul, tt, Mukhtashor Sirah Rasul Saw., Beirut Libanon: Darul 'Arabiyah

Yusuf, Muhammad Sayyid Muhammad, t.t, At-Tamkin Liummat alIslam Fi Dloui al-Qur'an al- Karim, Mesir: Darusalam

Zulfa, M, 2015, "Transformasi dan Pemberdayaan Umat Berbasis Masjid”, INFERENS Jurnal Penelitian Sosial Keagamaan Vol. 9, No. 1 (Juni)

Zuraidah dan Aizan, Pendidikan Integratif dalam Islam: Kesepaduan Iman, Ilmudan Amal, Jurnal Al-Muqaddimah, Volume2, Issu 2,dalam http:/ /e-journal.um.edu.my/public/article-view.php?id=6873, diunduh 28 Desember 2015 